\title{
Polski ślad na budowie wspólnej polityki energetycznej Unii Europejskiej.
}

\author{
Z Jerzym Buzkiem rozmawia Wojciech Jakóbik
}

\section{Jakie były cele polskiej polityki gazowej na arenie międzynarodowej w ostatnim półwieczu?}

Mówiąc najkrócej: bezpieczeństwo dostaw przy zachowaniu możliwie niskiej ceny. Niemal dokładnie pół wieku temu, w 1973 r. doszło do pierwszego kryzysu paliwowego - Bliski Wschód pogrążył się w wojnie, a ceny benzyny i ropy na świecie radykalnie wzrosły. My wtedy w Europie, w tym w wielu polskich miastach, dążyliśmy akurat do zmiany gazu koksowniczego na naturalny. Nie było jeszcze mowy o rynku gazu - jego ceny były regulowane, a najważniejszym celem była pewność dostaw. W latach dziewięćdziesiątych podpisaliśmy długoterminową umowę z Rosją i wybudowaliśmy gazociąg jamalski.

\section{Jakie są owoce tych działań?}

Zasadnicza poprawa bezpieczeństwa i zwrot w kierunku otwartego rynku gazu. Ale to nie efekt półwiecza, lecz dosłownie ostatniej dekady i kryzysów dostaw gazu z Rosji w latach 2006 i 2009. To właśnie wtedy, w 2010 r., przewodnicząc Parlamentowi Europejskiemu, ogłosiłem wraz z byłym przewodniczącym Komisji Europejskiej Jakiem Delorsem założenia europejskiej wspólnoty energetycznej, która położyła podwaliny pod unię energetyczną. Chodziło o wspólny rynek energii, europejskie badania w energetyce i koordynowanie zakupów gazu spoza Unii Europejskiej. Dzisiaj - m.in. dzięki zeszłorocznemu rozporządzeniu o bezpieczeństwie dostaw gazu, którego byłem sprawozdawcą - ciągłość dostaw do naszych domów, mieszkań, szpitali czy hospicjów jest gwarantowana w każdych warunkach. Mamy też wspólną ocenę, odpowiedzialność i zapobieganie przerwom w dostawach w poszczególnych regionach Europy. Dzięki inwestycjom ze środków unijnych, głównie z instrumentu „Łącząc Europę”, możliwy jest ponadto dwukierunkowy przepływ gazu na połączeniach transgranicznych wewnątrz UE. 


\section{Czego nie udalo się zrobić?}

Mimo wielu połączeń gazowych między krajami Unii otwarty rynek nie działa jeszcze sprawnie, jeśli chodzi o pełną przejrzystość cen, transparentne koszty przesyłu czy zasadę dostępu stron trzecich do gazociągu. Nie wszędzie mamy wystarczającą dywersyfikację dostaw, choć handel gazem skroplonym (LNG) znacząco poprawił sytuację. Nie wszystkie rurociągi dostawcze do UE podlegają przy tym prawu unijnemu - dotyczy to m.in. istniejącego już Nord Stream i równie kontrowersyjnego Nord Stream 2, którego budowa właśnie się zaczyna. Ostrze wypływających z tych projektów zagrożeń mogłaby stępić rewizja dyrektywy gazowej, której jestem sprawozdawcą z ramienia Parlamentu Europejskiego. Niestety, kilka państw członkowskich już od ponad roku blokuje prace prowadzone nad nią w Radzie UE.

\section{Jak na polską politykę gazową wpłynęła integracja europejska?}

Radykalnie poprawiła bezpieczeństwo dostaw. Bez Unii ani pierwsze, ani drugie rozporządzenie o bezpieczeństwie dostaw gazu - wspominałem o nim przed chwilą - nie byłyby możliwe. Europa ma dziś zasilanie gazem z kilku kierunków: Libii, Algierii, Norwegii, Rosji, ze złóż holenderskich i duńskich oraz z terminali LNG, a dzięki coraz lepszym połączeniom transgranicznym możemy otrzymywać gaz z każdego z tych kierunków (choć oczywiście może się on różnić ceną). Nasz terminal w Świnoujściu powstał przy wydatnym wsparciu ze środków unijnych. Od niemal dziesięciu lat obowiązuje również tzw. trzeci pakiet energetyczny, umożliwiający tworzenie konkurencyjnego, transparentnego i bezpiecznego rynku dostaw gazu w Unii Europejskiej.

\section{Jak ocenić i porównać projekty terminalu LNG i Baltic Pipe w kontek- ście polityki gazowej?}

Oba te projekty spowodują, że nasza bezwarunkowa zależność od rosyjskiego gazu odejdzie do przeszłości. Warto przypomnieć, że rząd, którym kierowałem w latach 1997-2001, w pełni wynegocjował budowę analogicznego do Baltic Pipe gazociągu z Norwegii i Danii do Polski. Niestety, z do dzisiaj niezrozumiałych powodów nasi następcy zrezygnowali w 2002 r. z podpisania ostatecznej umowy na jego budowę. Niewybaczalna decyzja i wielka szkoda!

\section{Czy Polska powinna i może wpłynąć na powstanie wspólnej polityki ga- zowej UE?}

To dość zaskakujące pytanie! Ta polityka de facto już przecież istnieje, a Polska wpływa na nią w istotny sposób od lat. Już w 2001 r., gdy jeszcze 
nie byliśmy w UE, uzyskałem wsparcie Komisji Europejskiej pod przewodnictwem Romano Prodiego dla budowy wspomnianego gazociągu z Danii i Norwegii. Europejska wspólnota energetyczna w roku 2010 to był pomysł francusko-polski, od nas wypłynęła także niemal sfinalizowana już inicjatywa unii energetycznej. Mam nadzieję, że także moją obecną pracę w PE - w charakterze sprawozdawcy rozporządzenia o bezpieczeństwie dostaw gazu i dyrektywy gazowej - trudno odbierać inaczej niż jako element polskiego wkładu we wspólną politykę gazową Unii.

\section{Czy jest ona do utrzymania?}

Nie słyszę, by istniały jakieś istotne zagrożenia ze strony instytucji UE. Pewnym wyzwaniem są jedynie niektóre państwa członkowskie lub firmy, które nie chcą słyszeć o solidarności (NS2!) czy pełnej konkurencji na rynku gazu. Myślę, że w Polsce również nie jesteśmy od tego ostatniego problemu zupełnie wolni.

\section{Jak kryzys integracji europejskiej wpływa na polską politykę gazową?}

Na szczęście nie dostrzegam tutaj istotnego wpływu. Mam poważne zastrzeżenia co do niektórych posunięć obecnego polskiego rządu w sprawach europejskich, ale akurat nie w polityce gazowej.

\section{Czy ostatecznym celem powinna być obecnie suwerenność energetyczna?} A może współzależność w federacji europejskiej? Jakie są pana prognozy?

Żadna z tych skrajności. Suwerenność warto zagwarantować, ale zawsze może zdarzyć się kryzys. Wtedy niezbędni są nasi partnerzy - z zachodu, z południa, a w przyszłości także z północy. Europejskie rozwiązania gwarantują nam ich wsparcie. Trzeba dokończyć budowę rynku gazu i wyeliminować luki w prawie Unii Europejskiej (zwłaszcza w odniesieniu do gazociągów dostawczych z krajów trzecich), zbudować Baltic Pipe i w pełni wykorzystać terminal w Świnoujściu. Federacja nie ma tu moim zdaniem nic do rzeczy. 